\title{
On limits of the distribution range of the Crimean rock lizard Darevskia lindholmi (Sauria: Lacertidae)
}

\author{
O. V. Kukushkin ${ }^{1,2} \bowtie$, I. S. Turbanov ${ }^{3,4}$, R. A. Gorelov ${ }^{5}$, A. G. Trofimov ${ }^{6}$ \\ ${ }^{I}$ T. I. Vyazemsky Karadag Scientific Station - Nature Reserve of the Russian Academy of Sciences - \\ Branch of A. O. Kovalevsky Institute of Biology of the Southern Seas of Russian Academy of Sciences \\ 24 Nauki St., Kurortnoe stm., Theodosia 298188, Russia \\ ${ }^{2}$ Zoological Institute of Russian Academy of Sciences \\ 1 Universitetskaya embankment, Saint Petersburg 199034, Russia \\ ${ }^{3}$ I. D. Papanin Institute for Biology of Inland Waters of Russian Academy of Sciences \\ 109 Borok stm., Yaroslavl' Region 152742, Russia \\ ${ }^{4}$ Cherepovets State University \\ 5 Lunacharsky Avenue, Cherepovets 162600, Russia \\ ${ }^{5}$ Samara Federal Research Center of RAS, \\ Institute of Ecology of the Volga River Basin of Russian Academy of Sciences \\ 10 Komzina St., Togliatti 445003, Russia \\ ${ }^{6}$ A. M. Nikolsky Herpetological Society \\ 15 Kolobova St., Sevastopol 299038, Russia
}

\section{Article info}

Original Article

https://doi.org/10.18500/1814-6090-2021-213-4-101-122

Received 26 August 2021, revised 23 September 2021 accepted 29 September 2021

\begin{abstract}
New data on the boundaries of the distribution range of the Lindholm rock lizard (Darevskia lindholmi), an endemic of the Crimean Peninsula, are presented. This petrophilous lizard inhabit a wide range of biotopes in various landscape levels of the Mountainous Crimea. The upper boundary of $D$. lindholmi distribution in the southwest of the Main Range of the Crimean Mountains reaches an elevation of $1,520 \mathrm{~m}$ a.s.l. (Ai-Petrinskaya Yayla, KemalEgerek Mountain), while on the other high uplands with altitudes above $1.5 \mathrm{~km}$ and colder climate (Babugan and Chatyrdag), the species was traced only up to $1,250-1,320 \mathrm{~m}$ a.s.l. The northern border of $D$. lindholmi range in the western part of the Crimean Mountains runs along the Outer Foothill Range (the right bank of the Alma River), while in the eastern part it corresponds the northernmost rocky massifs of the Inner Foothill Range to the north of $45^{\circ} \mathrm{N}$ latitude. Isolated marginal populations found in the forest-steppe or phrygana-steppe landscapes of the Foothills and arid Southeastern Coast differs significantly in their distance from the main habitat of the species, lizards' abundance and density. A hypothetical history of the formation of the current range of the Lindholm lizard is discussed.
\end{abstract}

Keywords: Darevskia (saxicola) complex, Crimean Mountains, geographical isolate

Acknowledgements: The work was executed in the framework of research topics of the State Task of the Ministry of Science and Higher Education of Russian Federation (No. 1210323000237, AAAA-A19-119020590095-9, 121051100109-1, and AAAA-A17-117112040040-3).

This is an open access article distributed under the terms of Creative Commons Attribution 4.0 International $\mathrm{Li}$ cense (CC-BY 4.0)

For citation: Kukushkin O. V., Turbanov I. S., Gorelov R. A., Trofimov A. G. On limits of the distribution range of the Crimean rock lizard Darevskia lindholmi (Sauria: Lacertidae). Current Studies in Herpetology, 2021, vol. 21, iss. 3-4, pp. 101-122 (in Russian). https://doi.org/ 10.18500/ 1814-6090-2021-21-3-4-101-122

\section{REFERENCES}

Amelichev G. M., Klimchouk A. B., Tymokhina E. I. Speleogenesis in the Cretaceous and Eocene successions of the Zuya and Burul'cha river valleys (eastern part of the Crimean fore-mountains). Speleology and Karstology, 2011, no. 7, pp. 52-64 (in Russian).
Beskaravaynyi M. M. Ptitsy morskikh beregov Yuzhnogo Kryma [Birds of Sea Shores of the Southern Crimea]. Simferopol, N. Orianda Publ., 2008. 160 p. (in Russian).

Bobra T. V., Bokov V. A., Ved' I. P., Garkusha L. Y., Zuev A. V., Kliukin A. A., Lagunov I. M., Lychak A. I., Panferov O. I., Sotskova L. M. Landshaftno-geofizi-

\footnotetext{
Corresponding author. Department of Biodiversity Studies and Ecological Monitoring, T. I. Vyazemsky Karadag Scientific Station - Nature Reserve - Branch of A. O. Kovalevsky Institute of Biology of the Southern Seas of Russian Academy of Sciences, Russia.

ORCID and e-mail addresses: Oleg V. Kukushkin: https://orcid.org/0000-0002-9311-0860, mtasketi2018@gmail.com; Ilya S. Turbanov: https://orcid.org/0000-0001-9441-2791, turba13@mail.ru; Roman A. Gorelov: https://orcid.org/0000-0002-0207-2951, gorelov.roman@mail.ru; Aleksandr G. Trofimov: trofimov_aleksan@mail.ru.
} 
cheskie usloviya proizrastaniya lesov yugo-vostochnoyi chasti Gornogo Kryma [Landscape-geophysical Conditions of Forest's Growing in Southeast Crimea]. Simferopol, Tavriya-Plus Publ., 2001. 136 p. (in Russian).

Bokov V. A. Transformatsiya landshaftno-ekologicheskikh protsessov $v$ Krymu $v$ XX veke-nachale XXI veka [Transformation of Landscape Ecology Processes in Crimea: XX-XXI Centuries]. Simferopol, Dolya Publ., 2010. 304 p. (in Russian).

Brauner A. Preliminary communication on reptiles and amphibians of Crimea, Kuban region, Volyn and Warsav provinces. Notes of Novorossiysk Society of Naturalists, 1905, vol. 28, pp. 1-14 p. (in Russian).

Vakhrushev I. B. Genesis of Adalar Rocks near Southern Coast of Crimea. Kultura narodov Prichernomorja, 2000, no. 14, pp. 11-14 (in Russian).

Vakhrushev B. A., Amelichev G. N. To an issue of the possibility of glaciation of the Crimean Mountains. Fizicheskaya geografiya i geomorfologiya, 2001, vol. 40, no. 1, pp. 1-11 (in Russian).

Vazhov V. I. Tselebnyi klimat [The Healing Climate]. Simferopol, Tavriya Publ., 1983. 96 p. (in Russian).

Ved' I. P. Klimaticheskyi atlas Kryma [Climatic Atlas of Crimea]. Simferopol, Tavriya-Plus Publ., 2000. 120 p. (in Russian).

Garkusha L. Y., Bagrova L. A. Composition, structure and modern environmental state of "dubki" at the forest-steppe belt of the Crimea mountains. Ekosistemy, ikh optimizatsiya $i$ okhrana, 2012, iss. 6, pp. 62-75 (in Russian).

Garkusha L. Y., Bagrova L. A., Pozachenyuk E. A. The diversity of Crimean landscapes with the Mediterranean elements of flora. Scientific Notes of Taurida $\mathrm{Na}$ tional V. I. Vernadsky University, Ser.: Geography, 2012, vol. 25 (64), no. 2, pp. 36-47 (in Russian).

Gorbunov R. V., Gorbunova T. Y., Kononova N. K. Climatic norms of the air temperature on the territory of the Crimean Peninsula. Kultura narodov Prichernomorja, 2014, no. 278, iss. 2, pp. 89-94 (in Russian).

Danielyan F. D. The influence of unfavorable aspects of surrounding of eggs of unisexual and bisexual forms of Armenian rock-lizards during incubation. Biological Journal of Armenia, 1971, vol. 24, no. 2, pp. 118126 (in Russian).

Darevsky I. S. Skal'nye yashcheritsy Kavkaza (sistematika, ekologiya i filogenezis polimorfnoyi gruppy kavkazskikh yashcherits podroda Archaeolacerta) [Rock Lizards of the Caucasus (Systematics, Ecology and Phylogenesis of the Polymorphic Group of Caucasian Lizards of Subgenus Archaeolacerta)]. Leningrad, Nauka Publ., 1967. 214 p. (in Russian).

Didukh Ya. P. Rastitel'nyi pokrov Gornogo Kryma (struktura, dinamika, evolutsiya i okhrana) [Vegetation Cover of the Mountainous Crimea (Structure, Development, Evolution and Protection)]. Kiev, Naukova dumka Publ., 1992. 256 p. (in Russian).

Doronin I. V. The use of GIS for the analysis of the distribution of rock lizards Darevskia (saxicola) com- plex (Sauria: Lacertidae). Current Studies in Herpetology, 2012, vol. 12, iss. 3-4, pp. 91-122 (in Russian).

Doronin I. V., Tuniyev B. S., Kukushkin O. V. Differentiation and taxonomy of the rock lizards Darevskia (saxicola) complex (Sauria: Lacertidae) according to morphological and molecular analyses. Proceedings of the Zoological Institute of RAS, 2013, vol. 317, no. 1, pp. 54-84 (in Russian).

Yena V. G., Yena Al. V., Yena An. V. 2001. Reserved Crimea as a focus of the nature of the Black Sea region. Kultura narodov Prichernomorja, 2001, no. 21, pp. 13-17 (in Russian).

Yena V. G., Yena Al. V., Yena An. V. Kratkyi geograficheskyi slovar' Kryma [Concise Geographical Dictionary of Crimea]. Simferopol, Bisnes-Inform Publ., 2011. 264 p. (in Russian).

Zinenko O. I., Goncharenko L. A. The Catalogue of Collections of the Museum of Nature of V. N. Karazin's Kharkiv National University. Reptiles (Reptilia): Rhynchocephalia; Squamata: Lisards (Sauria), Amphisbaenians (Amphisbaenia). Kharkiv, V. N. Karazin Kharkiv National University Publ., 2011. 100 p. (in Russian).

Karmyshev Yu. V., Pokusa R. V. Role of nearwater birds in the spreading of Sand lizard on the Sea of Azov islands. Povolzhskiy Journal of Ecology, 2003, no. 3, pp. 305-306 (in Russian).

Kidov A. A. To the study of the reproductie biology of the rock lizard (Darevskia saxicola, Reptilia, Lacertidae). Zoologicheskii zhurnal, 2020, vol. 99, no. 11, pp. 1293-1297 (in Russian). https://doi.org/10.31857/ S004451342008005X

Klimchouk A. B., Tymokhina E. I., Amelichev G. M., Dublyansky Y. V., Staubwasser M. Determination of the age of relief and denudation rates of the south-west part of the Inner Range of the Mountainous Crimea from karstological and speleological data. Speleology and Karstology, 2011, no. 7, pp. 29-39 (in Russian).

Klimchouk A. B., Amelichev G. M., Tymokhina E. I., Tokarev S. V. Hypogene karst of the eastern part of the Crimean fore-mountains. Speleology and Karstology, 2012, no. 8, pp. 18-49 (in Russian).

Kliukin A. A. Ekzogeodinamika Kryma [Exogeodynamics of Crimea]. Simferopol, Tavriya Publ., 2007. 320 p. (in Russian).

Kotenko T. I., Kukushkin O. V. Annotated lists of amphibians and reptiles of Crimean Nature reserves. Scientific Notes of the "Cape Martyan" Nature Reserve, 2010, iss. 1, pp. 225-261 (in Russian).

Kukushkin O. V. Materials to the study of the Eastern Crimea herpetofauna. Karadag Nature Reserve of National Academy of Sciences of Ukraine. Annals of Nature. Simferopol, SONAT Publ., 2004, vol. 20, pp. 191219 (in Russian).

Kukushkin O. V. New data on reproduction in two mass species of the True Lizards (Sauria: Lacertidae) in the Southern Crimea. Naukovyi visnyk Uzhgorods'kogo universitetu, Ser.: Biology, 2007, iss. 21, pp. 55-61 (in Russian). 
Kukushkin O. V. On patterns of spatial distribution of Lindholm's rock lizard Darevskia lindholmi (Sauria: Lacertidae) in the South-Eastern Coast of the Crimea. Samarskaya Luka: Problemy regionalnoyi i globalnoyi ekologii, 2009, vol. 18, iss. 1, pp. 68-75 (in Russian).

Kukushkin O. V., Sviridenko E. Y. Finds of melanistic specimens of a rock lizard Darevskia lindholmi (Reptilia, Sauria, Lacertidae) in the Crimea. Vestnik zoologii, 2002, vol. 36, no. 3, pp. 98 (in Russian).

Kukushkin O. V., Doronin I. V., Tuniyev B. S., Ananjeva N. B., Doronina M. A. Introduction of amphibians and reptiles at the Caucasus and the Crimea: An overview and some actual data. Current Studies in Herpetology, 2017, vol. 17, iss. 3-4, pp. 157-197 (in Russian). https://doi.org/10.18500/1814-6090-2017-17-3-4-157-197

Kukushkin O. V., Trofimov A. G., Turbanov I. S., Slodkevich V. Y. Herpetofauna of Sevastopol city (Southwestern Crimea): Species composition, zoogeographic analysis, landscape-zonal distribution, current status and protection. Ecosystem Transformation, 2019, vol. 2, no. 4, pp. 4-62. https://doi.org/10.23859/estr-190530

Kukushkin O. V., Ermakov O. A., Ivanov A. Y., Doronin I. V., Sviridenko E. Y., Simonov E. P., Gorelov R. A., Khramova M. A., Blokhin I. G. Cytochrome $b$ mitochondrial gene analysis-based phylogeography of a Sand lizard in the Crimea: Ancient refugium at the peninsula, late expansion from the North, and first evidence of Lacerta agilis tauridica and L. a. exigua (Lacertidae: Sauria) hybridization. Proceedings of the Zoological Institute of $R A S, 2020$, vol. 324, no. 1, pp. 56-99 (in Russian). https://doi.org/10.31610/trudyzin/2020.324.1.5

Lisetskii F. N., Marinina O. A., Buryak Zh. A. A Geoarcheological Survey of the Historical Landscapes of Crimea. Voronezh, Voronezh State University Publishing House, 2017. 432 p. (in Russian).

Muratov M. V. Kratkyi ocherk geologicheskogo stroeniya Krymskogo poluostrova [A Brief Outline of the Geological Structure of the Crimean Peninsula]. Moscow, Gosgeolteckhizdat Publ., 1960. 206 p. (in Russian).

Nikishin A. M., Alekseev A. S., Baraboshkin E. Y., Bolotov S. N., Kopaevich L. F., Nikitin M. Y., Panov D. I., Fokin P. A., Gabdullin R. R., Gavrilov Y. O. Geologicheskaya istoriya Bakhchisarayiskogo rayiona Kryma (uchebnoe posobie po Krymskoyi praktike) [The Geological History of the Bakhchisaray Region of Crimea (Tutorial for Crimean Student Field Practice)]. Moscow, Moscow University Press, 2006. 60 p. (in Russian).

Nikolsky A. M. Faune de la Russie et des Pays Limitrophes Fondee Principalement sur les Collctions Musee Zoologique de L'Academie Imperiale des Sciences de Petrograd. Reptiles (Reptilia). Vol. I. Chelonia et Sauria. Petrograd, Tipografiia Imperatorskoi Akademii Nauk, 1916. 534 p. (in Russian).

Panin A. G. The interaction of nature components and its role in the landscape forming on the example of the Western Crimean Foothills. Scientific Notes of Taurida National V. I. Vernadsky University, Ser.: Geography, 2012, vol. 25 (64), no. 2. pp. 81-99 (in Russian).
Panin A. G. On geobotanic zoning and mapping of Mountain Crimea. Scientific Notes of Taurida National V.I. Vernadsky University, Ser.: Geography, 2013, vol. 26 (65), no. 4, pp. 40-44 (in Russian).

Podgorodetsky P. D. Krym: Priroda. Spravochnoe izdanie [The Crimea: Nature. Reference Edition]. Simferopol, Tavriya Publ., 1988. 192 p. (in Russian).

Poplavskaya G. I. Vegetation of the Mountainous Crimea. Proceedings of V. L. Komarov Botanical Institute of Academy of Sciences of the USSR, Ser. 3: Geobotany, 1948, iss. 5, pp. 7-88 (in Russian).

Puzanov I. I. Preliminary results of the study of vertebrates fauna of the Crimean Reserve. In: A Study of the Fauna of the Crimean State Reserve. Collection of the papers. Moscow, Leningrad, Gosudarstvennoe meditsinskoe izdatel'stvo, 1931, pp. 5-39 (in Russian).

Sviridenko E. Y. On the distribution of Lindholm rock lizard, Darevskia lindholmi (Lantz et Cyrén). In: A. V. Kostyshin, G. V. Fesenko, eds. Registration of Animals under Red Data Book of Ukraine. Kyiv, I. I. Shmalhausen Institute of Zoology Publ., 2008, pp. 304-305 (in Ukrainian).

Tatarko K. I. Materials on batracho- and herpetofauna of the area of Karadag biological station of Academy of Sciences of Ukrainian SSR. Arhiv Karadagskoj nauchnoj stancii. Dokument no. 52. Rukopis' [Archives of Karadag Scientific Station, Document no. 52. Manuscript], 1940, pp. 1-7 (in Russian).

Tytar V. M. Analysis of home ranges in species: an approach based on modeling the ecological niche. Vestnik zoologii, 2011, no. 25, special issue. 93 p. (in Ukrainian).

Szczerbak N. N. On the systematics of Lacerta saxicola Eversmann of the Crimea and North Caucasus. Zoologicheskii zhurnal, 1962, vol. 41, iss. 9, pp. 13741385 (in Russian).

Szczerbak N. N. Zemnovodnye i presmykayuschiesya Kryma (Herpetologia Taurica) [Amphibians and Reptiles of the Crimea (= Herpetologia Taurica)]. Kiev, Naukova dumka Publ., 1966. 240 p. (in Russian).

Szczerbak N. N. Amphibians and reptiles. Study of the fauna and number of terrestrial vertebrates of Karadag (1981-1982) (final report). Letopis' prirody Karadagskogo gosudarstvennogo zapovednika AN USSR [Karadag State Reserve of Academy of Sciences of Ukrainian SSR. Annals of Nature], 1984, vol. 1, book 1, part 5, pp. 4-32 (in Russian).

Szczerbak N. N. Amphibians and reptiles. In: Priroda Karadaga [The Nature of Karadag]. Kiev, Naukova dumka Publ., 1989, pp. 194-197 (in Russian).

Yudin V. V. Geological Map and Sections of the Mountain and Foothill Crimea. Scale 1:200000. Simferopol, NPTs "Soiuzkarta" Publ., 2009, 2 sheets (in Russian).

Darevsky I. S. Relict areas of some lizard species located near the waterfalls as evidence of their formerly larger distribution over the Caucasus. Programme \& Abstracts: 13th Ordinary General Meeting of the Societas Europaea Herpetologica. Bonn, 2005, pp. 42. 
Gerasimenko N. Environmental changes in the Crimean mountains during the Last Interglacial - middle pleniglacial as recorded by pollen and lithopedology. Quaternary International, 2007, vol. 164-165, pp. 207220. https://doi.org/10.1016/j.quanit.2006.12.018

Gerasimenko N. P. Climatic and environmental oscillations in southeastern Ukraine from 30 to $10 \mathrm{ka}$, inferred from pollen and lithopedology. Geological Society of America Special Papers, 2011, vol. 473, pp. 117-132. https://doi.org/10.1130/2011.2473(08)

Kukushkin O., Ermakov O., Gherghel I., Lukonina S., Doronin I., Svinin A., Simonov E., Jablonski D. The mitochondrial phylogeography of the Crimean endemic lizard Darevskia lindholmi (Sauria, Lacertidae): hidden diversity in an isolated mountain system. Vertebrate Zoology, 2021, vol. 71, pp. 559-576.

Markova A. K., Simakova A. N., Puzachenko A. Y. Ecosystems of Eastern Europe in the Holocene Atlantic Optimum based on floristic and theriologic data. Doklady Earth Sciences, 2003, vol. 391A, no. 6, pp. 883-887.

Slavenko A., Maza E., Itescu Y. Results of the first herpetological survey of Israel's Mediterranean coastal is- lets. Russian Journal of Herpetology, 2021, vol. 28, no. 4, pp. 231-236. https://doi.org/10.30906/1026-2296-202128-4-231-236

Tabatschischin W. G., Sawjalow E. W., Tabatschischina I. E. Zur Ökologie der Felseidechsen-Art Darevskia lindholmi aus dem Großen Krimcañon. Mauritiana, 2006, Bd. 19, H. 3, S. 439-441.

Tuniyev B. Pulsation of lizard's area on the NorthWest Caucasus. In: Programme \& Abstracts: 12th Ordinary General Meeting of the Society Europaea Herpetologca. Saint Petersburg, 2003, pp. 164.

Turbanov I. S., Kukushkin O. V., Vargovitsh R. S. Amphibians and reptiles in the subterranean cavities of the Crimean Mountains. Russian Journal of Herpetology, 2019, vol. 26, no. 1, pp. 29-53. https://doi.org/10.30906/ 1026-2296-2019-26-1-29-53

Velo-Antón G. Recently isolated Atlantic neighbours: Insular populations of wall lizards (Podarcis bocagei and Podarcis guadarramae) across the Rias Baixas (Galicia, NW Spain). Herpetology Notes, 2019, vol. 12, pp. $1157-1163$. 